\title{
The Technological Content of China's Exports and the Need for Quality Upgrading
}

Kunwang Li and Ligang Song

\section{Introduction}

Over the past 30 years, trade liberalisation has gone hand-in-hand with domestic economic transformation in China. As a result, the Chinese economy has been increasingly integrated with the world economy. China's ever-increasing exports have positively contributed to its rapid economic growth in the following ways: trade encourages investment, which confers externalities on an economy, particularly if the investment goods come from abroad; greater trade means larger volumes of output and greater scope for specialisation, leading to learning by doing; and trade also leads to technology transfer, which enhances the prospect of faster total productivity growth (Thirlwall 2006). Over the period 1978-2008, the average annual growth rate of China's exports reached 18.1 per cent - much higher than the average growth rate of total world exports of about 6 per cent over the same period. In 2009, China surpassed Germany to become the world's largest exporter of commodities. China's exports now account for about 10 per cent of the world's total exports.

Consistent with China's underlying comparative advantage and pattern of change, the pattern and composition of its exports have also changed over time - from the predominant reliance on primary goods such as petroleum and agricultural products at the beginning of the reform period to labour-intensive products such as textiles and clothing during the first two decades of reform, further to capital-intensive products such as steel, machinery and automobiles in the current phase of industrialisation, and increasingly to technologyintensive products such as some hi-tech equipment, bio-products and green technology.

China is currently still at the mid-phase of industrialisation as measured by its current per capita income plus other macroeconomic indicators such as auto penetration, metal and energy intensity, capital stock per capita or the level of urbanisation. This means that its rapid manufacturing-led growth is expected to persist for some time and exports of manufactured products from China to world markets will continue to dominate the changing pattern of the global division of labour and to impact consequently on the ongoing structural changes in China and its trading partners.

China now, however, faces tremendous pressures and challenges to change its economic structure by accelerating the technological progress in its industries, upgrade its production towards producing high value-added products, and improve product quality and efficiency. This is mainly because China must seek to alter the composition of its economic activities to address issues of global imbalances, low efficiency and overcapacity in certain sectors of the economy, to respond to the conflict between its current growth model and the biosphere at 
local, national, regional and global levels, and to readjust its growth strategy in responding to the rising costs of labour, land, energy and minerals (McKay and Song 2010). A key task for China to succeed in making the necessary adjustment in its economic structure is to find ways of accelerating the pace of technological catch-up, through which it can realise quality upgrading in production and export, and ultimately achieve more balanced growth.

The improvement of export quality is not confined just to those more sophisticated manufacturing products, but applies also to low-end labour-intensive manufacturing products. This is because rising productivity could make a wider range of activities profitable, extending further up the lists of capital intensity and technological sophistication, without necessarily placing any pressure for contraction on labour-intensive industries in the traded-goods sector (Garnaut 2010).

A simple measure for capturing this progress is to examine how the technological content of China's exports changes and how the quality of its exports is improving over time. The purpose of this chapter is therefore to explore the dynamism of China's export structure from two dimensions: the changes in the technological content of its exports in the context of China's position in international vertical specialisation, and changes in the quality of its exports over time, which reflects the progress of industrial upgrading and the outcomes of learning by doing. The chapter also discusses some policy implications for understanding China's export growth and the risks involved for China to continue reliance on its current export-oriented growth model.

\section{Technological content of China's exports: a review}

Since the mid-1990s, the proportion of Chinese manufactured exports has accounted for more than 90 per cent of the total exports from China. Since then, the commodity composition of manufactured exports has undergone great change (Table 5.1). From 1995 to 2009, the export share of China's low technology-intensive (and labour-intensive) products - though still accounting for a relatively large share in China's total exports-declined from 48 per cent to 31 per cent, which is still well above the world average share of 14 per cent. This suggests that on the one hand, the relative abundance of labour in China remains a key determinant of manufactured trade in low-technology labour-intensive products. On the other hand, the dynamic characteristics of China's exports also show that the proportion of high technology-intensive products has increased significantly-rising from 15 per cent to 34 per cent during the same period. The proportion of medium technology-intensive (and capital-intensive) products has also shown a rising trend, but at a much slower rate of change. The comparison with the world averages shows that the changes in the structure of China's exports have been significantly faster than the world average, especially for high technology-intensive products. In this chapter, we will explore whether this shift in export structure towards high technology-intensive production has marked a significant change in China's underlying comparative advantage, and whether the trend means that China has been catching up with more advanced industrialised countries in terms of its overall level of technology and narrowing the gap of economic development with industrialised countries. 
Table 5.1 Changing structure of exports by levels of technology: China and the world, 1995-2009 (per cent)

\begin{tabular}{|l|l|l||c|c|c|}
\hline \multicolumn{2}{|c|}{} & 1995 & 2000 & 2005 & 2009 \\
\hline \multirow{3}{*}{ Low tech } & China & 48.4 & 42.5 & 33.0 & 31.8 \\
\cline { 2 - 6 } & World & 16.6 & 15.1 & 14.2 & 14.0 \\
\hline \multirow{3}{*}{ Mid tech } & China & 18.1 & 19.1 & 21.4 & 23.6 \\
\cline { 2 - 6 } & World & 33.2 & 31.8 & 33.1 & 31.8 \\
\hline \multirow{3}{*}{ High tech } & China & 15.2 & 24.5 & 33.2 & 34.0 \\
\cline { 2 - 6 } & World & 19.0 & 19.0 & 20.5 & 20.2 \\
\hline \multirow{2}{*}{ Others } & China & 18.3 & 13.9 & 12.4 & 10.7 \\
\cline { 2 - 6 } & World & 31.1 & 30.5 & 32.2 & 34.0 \\
\hline
\end{tabular}

Notes: Manufactured exports are classified as low, medium or high technology intensive based on the export classifications used in Lall (2000). 'Others' includes primary goods and resource-based manufactured goods.

Sources: Authors' calculations using the data taken from Information Center of China Customs (various years) and UNSD (n.d.).

The increasing sophistication of China's exports, especially with respect to the increasing quality and technological content, has generated some debate in the literature regarding the implications of this change for understanding the growth of exports from China. As Rodrik (2006) says, 'it is not how much but what you export that matters'. Some studies empirically support the view that China's export structure is becoming more and more sophisticated over time, including Rodrik (2006), who finds that the rapid growth of Chinese exports is increasingly biased in favour of its exports with high complexity or high technology content. As these products have both higher productivity and a higher tendency for growth, their development has led to a rapid increase in overall exports. Rodrik also finds that the complexity of China's exports is much higher than that of countries with the same level of development or a similar pattern of factor endowments, with its export structure being more similar to that of high-income countries. This suggests that China's foreign trade pattern does not follow exactly its underlying comparative advantage, but instead has demonstrated a pattern of development that is inconsistent with the level of China's current development. In other words, China might have achieved some kind of technological leapfrogging that is reflected in its patterns of exports. Schott (2008) also argues that China's export structure is increasingly overlapping in quality with industrialised countries. Using the same method as Rodrik (2006), Yao and Zhang (2008) estimate the domestic technological content of exports of two Chinese coastal provinces producing a huge amount of tradenamely, Jiangsu and Guangdong. They conclude that the domestic technological content of China's exports shows a V-shaped dynamic, suggesting that the technological content of China's exports is now at a stage of acceleration. Based on this finding, they conclude that the domestic technological content of China's exports will continue to rise in the future.

These analyses could, however, be misleading in that they might overlook the particularities of Chinese export trade, especially with respect to the variations of the structure of China's exports and the pattern of trade growth. Since the mid-1990s, China's integration with the global economy has intensified the international segmentation of production processes, and has accelerated the process of transferring labour-intensive 
stages of production from other countries to China. Since the end of the 1990s, processing trade has continually accounted for half of Chinese foreign trade. After 2008, although the position of processing trade weakened, the proportion of processing trade in total trade remained at 48 per cent. Processing trade reflects the fact that China is in the downstream stage of international production fragmentation. Basic research, research and development (R\&D) expenses and the intermediate stages of production are located mostly in foreign countries. China basically imports intermediate goods, then processes or assembles them domestically and mainly exports the final products to the United States and European and other industrialised markets. Thus, the technological content or complexity of its exports is not entirely provided by the Chinese producers, but rather should be partly attributed to foreign firms. Without considering China's special position within this international vertical specialisation, there will be an overestimation of the results of the complexity or technological content of the overall exports. Yao and Zhang (2008) note this problem, and develop a more reasonable definition of domestic technological content in China's exports. They use the same methods as Rodrik and others, which rank the technological content of export goods by their 'income content'. This approach means that the technological level or complexity embodied in production and trade is consistent with the general level of income among different countries. The more similar their income levels are, the more similar levels of technological contents they have in production and trade. This kind of approach has the limitation that it tends to look at the impact of horizontal differentiation between products (production technological condition can be seen as homogeneous) but overlooks vertical differentiation. In the international trade theories concerning product differentiation, export growth can be realised not only by the extensive margin on products and the expansion of product varieties, but also by the quality margin. It is therefore critical to examine vertical specialisation as well, in order to arrive at an accurate picture of China's export quality and technological content.

\section{Technological content of exports with vertical specialisation}

With the deepening of international specialisation, which has extended from interindustry and intra-industry specialisation to intra-product specialisation, vertical specialisation among production processes has become the new source of international trade development. Along with continually decreasing costs of transportation and communication, different stages of production have been increasingly dispersed into different countries or regions, leading to the rapid development of component trade ( $\mathrm{Li}$ et al. 2010). Techniques used at different stages of the vertical production chain will be different. From upstream to downstream production stages, there exists an ascending trend of labour intensiveness in the production process as the processes themselves have become more standardised. The opposite trend in the embodied technology in these processes occurs, however, as competition forces upstream firms to become more innovative in developing new products as well as new ways of production. In this context, the nearer to the end of the production chain a country is located, the higher will be the proportion of the embodied technology of its exports coming from other countries. 
To examine how China positions itself in the production chain of international specialisation, we use the Broad Economic Classification (BEC) method to divide China's foreign trade into different production stages. Table 5.2 shows that China's imports of intermediate products, though declining, account for relatively high shares in its total imports, while exports are predominantly final products. Within the intermediate-goods imports, the proportion of parts and components shows a declining trend, but has always been higher than the proportion of semi-finished products. Final product exports comprise mainly consumer goods, but the proportion of capital-goods exports is increasingly rising, with a trend that looks likely to surpass that of consumer goods in the near future. This pattern of trade in China generally reflects the fact that Chinese manufacturing has tended to concentrate in the downstream phase of international vertical specialisation. As shown in Figure 5.1, after joining the World Trade Organisation (WTO), China's processing trade has maintained the same proportion of about 50 per cent of total exports, with a declining trend demonstrated only in recent years. Such a trend of declining share of component trade might reflect the fundamental structural changes in China's position in international specialisation.

Table 5.2 China's pattern of trade by stage of production, 1995-2009 (per cent)

\begin{tabular}{|l|r|r|r|r|}
\hline \multirow{2}{*}{} & \multicolumn{2}{|c|}{ Imports } & \multicolumn{2}{c|}{ Exports } \\
\cline { 2 - 5 } & 1995 & 2009 & 1995 & 2009 \\
\hline Total & 100.0 & 100.0 & 100.0 & 100.0 \\
\hline Primary goods & 9.7 & 24.5 & 4.5 & 1.0 \\
\hline Manufactured goods & 90.3 & 75.5 & 95.5 & 99.0 \\
\hline Intermediate goods & 61.0 & 53.2 & 31.3 & 37.6 \\
\hline Semi-finished goods & 14.7 & 22.8 & 7.4 & 17.6 \\
\hline Parts and components & 46.3 & 30.5 & 23.9 & 20.0 \\
\hline Final goods & 29.3 & 22.3 & 64.2 & 61.3 \\
\hline Consumption goods & 7.0 & 6.1 & 52.4 & 32.5 \\
\hline Capital goods & 22.3 & 16.2 & 11.8 & 28.8 \\
\hline
\end{tabular}

Source: Authors' calculations using the data taken from Information Center of China Customs (Various years).

Figure 5.1 Share of processing trade in China's total exports

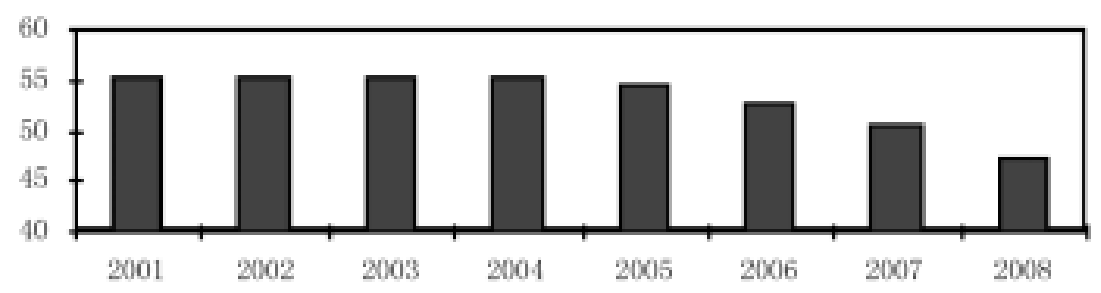

Source: Authors' calculations using data taken from Information Center of China Customs (Various years). 
This pattern of China's trade and specialisation raises a cautious note when one examines the relationship between changes in China's export structure and the technological content of exports. The question we ask is whether the improvement of the export structure reflects technological progress in production?

To better explain changes in the technological level of China's exports, we calculate the structure of exports with processing trade and without processing trade and compare them to see whether there are substantial differences in the technological content of China's exports under the two circumstances. Here we apply the product technology classification standard in Lall (2000) to divide manufactured exports into four categories: resource-based products (RP), low-technological products, medium-technological products, and high-technological products. Within the category of low-technological products there exist two subcategories: textile and apparel products (LT1) and other low-technological products (LT2). Within the category of medium-technological products there exist three subcategories: automotive products (MT1), medium-technological processing products (MT2), and engineering mechanical products (MT3). Within the category of high-technological products there exist two subcategories: electrical and electronic products (HTl) and other high-technological products (HT2). There are altogether eight categories of products.

During 2001-08, the proportion of high-tech manufactured exports showed a trend of continuous annual growth, which exceeded that of low-tech manufactured goods to become the most important product type of export. At the same time, exports of medium-tech manufactured goods also showed a trend of continuous annual expansion.

The results also show that the proportions of MT1, MT3, HT1 and HT2 products in China's overall exports have increased (Table 5.3). We can see that the types of products that have demonstrated an increasing trend in the proportion of exports are all located at the higher end of the technological chain. Although the proportions of LT1 and LT2 products showed a declining trend in total exports and were less than those of the HTl and MT3 products in 2008, the total proportion of about 30 per cent of low-tech products in total exports in China continued to occupy an important position. That is, the advantages of cheap labour in China still play an important role in determining its pattern of exports.

Table 5.3 Structure of China's manufactured exports by product, 2001-08 (per cent)

\begin{tabular}{|c|c|c|c|c|c|c|c|c|}
\hline \multirow{2}{*}{ Year } & \multirow{2}{*}{ Resource based } & \multicolumn{2}{|c|}{ Low tech } & \multicolumn{3}{|c|}{ Medium tech } & \multicolumn{2}{c|}{ High tech } \\
\cline { 3 - 9 } & & LT1 & LT2 & MT1 & MT2 & MT3 & HT1 & HT2 \\
\hline 2001 & 9.4 & 23.1 & 17.2 & 1.6 & 5.0 & 12.9 & 23.1 & 2.2 \\
\hline 2002 & 9.0 & 22.7 & 15.5 & 1.7 & 4.4 & 14.0 & 26.1 & 2.1 \\
\hline 2003 & 8.2 & 20.5 & 15.2 & 1.7 & 4.7 & 14.1 & 28.2 & 2.3 \\
\hline 2004 & 7.8 & 17.8 & 15.2 & 1.9 & 5.4 & 14.0 & 30.3 & 2.6 \\
\hline 2005 & 8.0 & 18.2 & 14.8 & 2.0 & 4.8 & 14.6 & 30.4 & 2.7 \\
\hline 2006 & 7.9 & 17.7 & 15.3 & 2.1 & 4.5 & 15.2 & 31.3 & 2.6 \\
\hline 2007 & 8.0 & 14.1 & 18.4 & 2.3 & 4.4 & 16.9 & 29.3 & 2.8 \\
\hline 2008 & 8.3 & 15.6 & 14.2 & 2.7 & 4.8 & 16.7 & 28.3 & 3.1 \\
\hline
\end{tabular}

Source: Authors' calculations using the data taken from Information Center of China Customs (Various years). 
Among China's exports of manufactures, the proportions of LT1, LT2 and HT1 products are higher than the world average, while those of MT1, MT2, MT3 and HT2 are lower than the world average (from 2000 to 2005). The medium-tech manufactures comprise mainly automotive products, medium-tech processed products and engineering machinery, which are all capital-intensive products. These calculations show that the proportion of China's automobile exports has been less than one would expect given the rapid growth of that industry in China. Part of the reason for this might be the fact that the industrial concentration of the automotive industry is relatively low and the industry depends heavily on imported technology. But we can also see that the proportion of such exports has gradually been increasing. The proportions of China's medium-tech processed exports, such as chemical products and synthetic fibres, are lower than the world average, indicating that the technological level in these categories of exports has further room to develop. The proportion of exports of engineering machinery was slightly lower than the world average, but in recent years it has shown a steady upward trend and has now reached the world average. HT1 products have become the greatest force in influencing China's export growth. Such a conclusion seems to confirm the point of view of Rodrik, Schott and others. It is noteworthy, however, that we observe the unsatisfactory performance of exports of medium-tech manufactured goods (MT1, MT2 and MT3), and these kinds of products best reflect China's technological depth. The export share of these three products has been lower than that of the world average (from 2000 to 2005).

The calculations show that changes in the exports of these listed products might not be an accurate reflection of China's technological level. Because of the high share of processing trade, the technology level embodied in China's exports might come mainly from other countries or regions through the direct investments of multinational corporations. If we analyse a country's trade structure and examine the competitiveness of its export products merely using the traditional technological content method of classification, we can only tell what kind of products the country exported, without gaining knowledge about the true technological content for the country. It is therefore important that we eliminate the impact of processing trade in order to more accurately assess the technological content of China's exports.

Table 5.4 shows the structure of manufactured exports without including processing trade. In contrast with the findings above, this shows clearly that low-tech manufactured exports occupy the absolute dominant position in China's total exports. The proportion of high-tech exports of manufactured goods is even lower than that of medium-tech products, which has the lowest share of exports among the three categories. Although the proportions of medium and high-tech products such as MT1, MT2, MT3 and HT1 products have also shown a rising trend, the absolute proportions of these products are very low compared with low-tech manufactures of LT1 and LT2, which themselves are lower than the world average and are not the main force in determining China's overall exports. At the same time, the proportion of HTl products has shrunk a great deal compared with the previous analysis and is far below the world average. In the category of low-tech manufactures, the proportion of LT1 products has declined since 2006, but the proportion of LT2 products actually shows an upward trend, both of which together maintained a level of 40 per cent - higher than the 30 per cent figure found without removing processing trade. LT2 has replaced the previous 
dominant position of $\mathrm{HTl}$ products in this ranking. These results show that of those exports for which the production process has been truly finished in China, low-tech products still account for a large proportion, and, in that context, cheap labour is still the largest source of comparative advantage in determining China's pattern of foreign trade.

Table 5.4 Structure of China's manufactured exports excluding processing trade, 2001-08 (per cent)

\begin{tabular}{|c|c|c|c|c|c|c|c|c|}
\hline \multirow{2}{*}{ Year } & \multirow{2}{*}{ Resource based } & \multicolumn{2}{|c|}{ Low tech } & \multicolumn{3}{c|}{ Medium tech } & \multicolumn{2}{c|}{ High tech } \\
\cline { 3 - 9 } & & LT1 & LT2 & MT1 & MT2 & MT3 & HT1 & HT2 \\
\hline 2001 & 18.1 & 33.1 & 20.7 & 2.7 & 6.8 & 10.1 & 5.9 & 2.5 \\
\hline 2002 & 16.8 & 34.9 & 19.3 & 2.7 & 6.7 & 9.7 & 7.4 & 2.4 \\
\hline 2003 & 15.6 & 33.2 & 20.9 & 3.1 & 7.0 & 10.0 & 8.0 & 2.2 \\
\hline 2004 & 13.9 & 29.7 & 22.6 & 3.5 & 9.2 & 10.3 & 9.0 & 1.9 \\
\hline 2005 & 13.7 & 30.6 & 22.7 & 3.6 & 7.8 & 10.9 & 9.1 & 1.7 \\
\hline 2006 & 12.7 & 29.3 & 24.0 & 3.9 & 7.2 & 11.4 & 9.9 & 1.6 \\
\hline 2007 & 12.4 & 23.6 & 29.2 & 4.2 & 6.7 & 12.7 & 9.8 & 1.6 \\
\hline 2008 & 12.2 & 23.4 & 23.8 & 4.6 & 6.9 & 15.1 & 12.2 & 1.9 \\
\hline
\end{tabular}

Source: Authors' calculations using the data taken from Information Center of China Customs (Various years).

The sharp reduction of the export proportions of HT1 and HT2 products when processing trade is eliminated from the calculation confirms our initial speculation that among most of China's exports of high-tech products, products involving processing trade account for a large proportion. After removing processing trade, the proportion of exports of HTl products declines sharply, which might more accurately reflect the actual technological level of China's exporting enterprises.

On the other hand, because processing trade is carried out mainly by foreign-owned enterprises, the proportion of processing trade in local enterprises' exports is far lower than that of foreign enterprises. Despite the significant decline of the proportion of high-tech products after removing processing trade, the growth rate of various types of products remained at a higher level compared with the situation before removing processing trade (not including resource-based products and that of HT2 products is slightly lower than before). For HTl products, their average annual growth rate after removing processing trade was 45 per cent, while that of the previous case without excluding processing trade was 32 per cent. This might show that there is growth potential for increasing the technological level of China's local exporting enterprises, which is consistent with the conclusion of Yao and Zhang (2008).

The evidence above is a negation of the point of view of Rodrik and others by showing that the technological content embodied in the product does not accurately reflect China's own technological level. In reality, the international specialisation in which China has been involved has deepened further into the intra-product level. It is therefore not a clear-cut process to determine how much of the technological content of China's exports is determined by its own contribution. Without taking this fact into account, one might greatly overestimate the technological content of China's exports. In fact, the fundamental 
pattern of China's foreign trade does not break away from its underlying comparative advantage. This also suggests that China's export structure does not much exceed the level of its development.

\section{China's position on the quality ladder}

If technological content is an important indicator for measuring the improvement of trade structure then product quality can be used more directly to reflect whether a country's export structure has experienced a 'substantial' change. Differences between product qualities are linked to differences in consumers' evaluations of these qualities. These evaluations about product quality are reflected in changing consumer preferences and consequently product prices, with the reservation prices of high-quality products being higher than those of lowquality products. Therefore, we can use the price of a product as a proxy to evaluate its quality. In the international market, for the same kinds of products coming from different countries, the ones with higher prices are often of relatively higher quality. The export price is usually expressed by an indicator of unit value, which is defined as the amount or value of exports divided by the quantity of exports. There are some flaws to using exportvalue indicators to measure export quality (Aiginger 1995, 1997), but it is a simple method to use.

Here we use the price-quality range method to divide exports into three categories by their quality: low-quality products, medium-quality products and high-quality products (Fontagné et al. 2007). The specific sub-method is as follows.

We first calculate the world average export unit value, $\overline{U V}$ (the trade-weighted average unit value of exports of the same product from all countries), at the product level. If the export unit value of a product is below 75 per cent of the world average then it is considered a low-quality product; if the export unit value of a product is higher than 125 per cent of the world average then it is regarded as a high-quality product; and the products with export unit values ranging between those two levels are regarded as medium-quality products. That is, the export unit values for low-quality products lie in the interval $[0,0.75 \overline{U V}]$; those for medium-quality products lie in the interval $[0.75 \overline{U V}, 1.25 \overline{U V}]$ and those for high-quality products lie in the interval $[1.25 \overline{U V}, \infty]$.

Data measuring the quality of exports are collected from BACI database of the French Institute for Research on the International Economy (CEPII) (Gaulier and Zignago 2010). The BACI database includes export unit values and trade data for products at the HS sixdigit level, in which the transportation costs and insurance costs have been removed when providing the unit value.

Table 5.5 shows the quality distribution of manufactured products for some of the world's leading export countries including China in 2007. First, the quality of export products of industrialised countries is obviously higher than that of the developing countries, which verifies the positive correlation between the level of economic development and the product quality. Second, we find that China has a special export quality range among the countries listed. The share of high-quality products in China's manufactured exports is not only far below the world average, but also significantly lower than those countries with similar 
levels of development, such as Brazil, India and Mexico. On the other hand, the share of low-quality products ranks the highest in China's manufactured exports, and China is the only country whose low-quality products account for more than half of the country's total manufacturing exports. Therefore, China's exports depend more on low-quality products, which become the main driving force to promote China's export growth. From this point of view, China not only has a large gap in quality with the industrialised countries, it also has a gap with developing countries.

Table 5.5 Structure of manufactured exports by quality for selected countries, 2007 (per cent)

\begin{tabular}{|l|c|c|c|}
\hline & High quality & Medium quality & Low quality \\
\hline China & 11.9 & 37.9 & 50.2 \\
\hline Germany & 32.9 & 36.4 & 30.6 \\
\hline United States & 27.4 & 42.6 & 30.0 \\
\hline Japan & 28.4 & 36.7 & 34.9 \\
\hline France & 32.3 & 37.5 & 30.2 \\
\hline Italy & 31.3 & 37.0 & 31.7 \\
\hline United Kingdom & 34.1 & 34.6 & 31.3 \\
\hline Korea & 27.1 & 38.0 & 34.8 \\
\hline India & 16.9 & 45.7 & 37.4 \\
\hline Brazil & 13.1 & 47.3 & 39.6 \\
\hline Mexico & 19.8 & 39.4 & 40.8 \\
\hline World & 24.7 & 37.8 & 37.5 \\
\hline
\end{tabular}

Source: Authors' calculations using the data taken from Gaulier and Zignago (2010).

The dynamic characteristics of the qualities of Chinese exports are shown in Table 5.6. During 2001-07, the proportion of high-quality products in China's manufactured goods showed a declining trend-falling from 14.8 per cent in 2001 to 11.9 per cent in 2007; lowquality products showed similar trends of decline; while the proportion of medium-quality products showed an increasing trend. These results show that upgrading of the quality of Chinese exports has been taking place only in medium-quality products, while the upgrading of high-quality products had not shown any obvious sign of increase by 2007 . 
Table 5.6 Structure of China's manufactured exports by quality, 2001-07 (per cent)

\begin{tabular}{|l|l|r|r|r|r|r|r|r|}
\hline \multicolumn{2}{|c|}{} & 2001 & 2002 & 2003 & 2004 & 2005 & 2006 & 2007 \\
\hline \multirow{4}{*}{ Total } & High quality & 14.8 & 12.7 & 9.2 & 10.2 & 17.1 & 11.3 & 11.9 \\
\cline { 2 - 9 } & Medium quality & 28.4 & 26.9 & 24.2 & 24.0 & 33.1 & 46.2 & 37.9 \\
\cline { 2 - 9 } & Low quality & 56.8 & 60.4 & 66.7 & 65.9 & 49.8 & 42.5 & 50.2 \\
\hline \multirow{4}{*}{ High tech } & High quality & 15.0 & 13.4 & 10.4 & 11.9 & 17.0 & 12.9 & 10.1 \\
\cline { 2 - 9 } & Medium quality & 13.5 & 17.3 & 17.2 & 18.6 & 31.5 & 48.1 & 34.8 \\
\cline { 2 - 9 } & Low quality & 71.6 & 69.3 & 72.5 & 69.5 & 51.5 & 39.0 & 55.1 \\
\hline \multirow{3}{*}{ tech } & High quality & 13.7 & 12.9 & 7.8 & 8.5 & 15.3 & 8.8 & 13.5 \\
\cline { 2 - 9 } & Medium quality & 25.8 & 24.4 & 20.9 & 21.4 & 33.9 & 45.6 & 35.3 \\
\cline { 2 - 9 } & Low quality & 60.5 & 62.7 & 71.3 & 70.0 & 50.9 & 45.6 & 51.2 \\
\hline \multirow{3}{*}{ Low tech } & High quality & 14.0 & 11.2 & 7.8 & 7.1 & 18.8 & 11.0 & 12.3 \\
\cline { 2 - 9 } & Medium quality & 35.3 & 33.2 & 29.1 & 27.7 & 33.0 & 46.0 & 42.7 \\
\cline { 2 - 9 } & Low quality & 50.7 & 55.7 & 63.2 & 65.2 & 48.2 & 43.0 & 44.9 \\
\hline
\end{tabular}

Source: Authors' calculations using the data taken from Gaulier and Zignago (2010).

The dynamic change in China's manufactures with different types of technological content appears to be unique. For example, relative to the medium and low technologyintensive products, the proportion of high-quality products in high-tech manufactured exports is the lowest, while that of the low-quality products is the highest. This confirms the so-called assertion of 'low-end processing in high-end industry'. This is also consistent with the conclusion in the previous section that the proportion of high-tech manufactured goods sharply declined after removing processing trade from total trade.

These analyses could indicate that China's exports are in a relatively disadvantageous position in terms of international competition for quality. In these circumstances, one could ask why China's exports have maintained such rapid growth momentum in the international market. An answer to this question goes beyond China's rich factor endowments of cheap labour and even the Government's export-encouraging policies to look at the competitive strategies of Chinese enterprises. For a long time, Chinese enterprises have taken full advantage of cheap labour, using the means of low cost-based price competition to explore the international market continuously, particularly for those enterprises involved in export processing. In order to be price competitive, enterprises have paid more attention to cost control, and less attention to quality improvements. China's exporters therefore rely heavily on the export of low-cost, low-quality products to boost export growth. As the proportion of processing trade is too high in China's high-tech exports, high-tech products tend to have low-end processing and assembly in the domestic production processes with low value added. This is the basic reason why China's exports can be sold at cheap prices with low quality in the international market. 


\section{Risks in China's low-quality and low-cost export growth model}

With this conclusion, we can now evaluate the growth pattern of China's exports. Needless to say, the low-quality, low-cost export growth model has been a great success in the past three decades. Such a model for export growth, however, involves more and more risks in the changing international business environment. First, China is entering an era in which its 'demographic dividend' will begin to be exhausted (Wang and Cai 2009). This will have some important implications for future growth in China. According to the experiences of Japan and other industrialised countries, the negative impact of an ageing workforce on labour productivity needs to be made up by faster progress in innovation, otherwise it will be difficult to reverse the decline of productivity growth. More importantly, in the context of this analysis, against the background of rising wages and other costs of production, Chinese enterprises will be compelled to innovate in order to maintain their competitiveness on international markets. This will further push the structural change in the economy moving in the direction of producing and exporting more high value-added goods with improved quality.

Second, relying predominantly on low price competition has put great pressure on the exporting enterprises themselves. Although low price competition has allowed Chinese enterprises to occupy larger international market shares, it has also constantly squeezed corporate profits. Such a competitive strategy is not conductive to the sustainability of exporting enterprises and threatens their survival in the long term. As observed by Steinfeld (2007:291):

Chinese firms are structured in a fashion that allows them to compete extremely effectively on the basis of low cost in relatively low-value manufacturing activities. The problem is that this structure does not easily allow them to move upward in the production chain into more innovative, higher-return activities: control over brands, provision of unique services, or development of proprietary knowledge. To the extent that Chinese firms remain shut out of these activities and locked in basic manufacturing, they have no choice but to compete on the basis of cost, thus eroding their profit margins and further inhibiting efforts to upgrade.

Third, due largely to this low-cost-based competitiveness of China's exporters on international markets, the Chinese Government is extremely sensitive about policy adjustments that might nevertheless be appropriate, including renminbi (RMB) appreciation. This prevents China from exercising a more independent exchange rate policy in its macroeconomic management in the face of global imbalances and domestic economic overheating. Another example is that to protect its exporters in the face of lowcost competition, the Government has to implement the export tax rebate policy, which encourages the export of a large number of processing enterprises. As a result, part of the government tax rebate has become the main source of profit of these enterprises. Such a policy is distortionary in that it disturbs the 'level playing field' or the incentive structure of the enterprises and thereby is not conducive to the long-term development of those enterprises. For example, if there is total abolition of this policy, many companies could face bankruptcy. That is why such a policy is always recurring. Moving towards producing high 
value-added products with high quality by exporting enterprises will ease the pressure on the policy front as those products with high selling prices are less sensitive to policy changes with respect to the exchange rate and tax rebates.

Fourth, the expansion of China's low-cost, low-quality exports could easily lead to trade disputes, especially with industrialised countries. Precisely because the Chinese enterprises have an obvious price advantage in international competition, their exports have had a great impact on the similar industries and enterprises in importing countries, which can easily trigger trade protectionism in these countries. China has become the largest targeted country of anti-dumping in the world. According to the statistics released by the WTO, from 1995, when the WTO was founded, to June 2008, there were altogether 3305 antidumping investigations launched worldwide, of which 640 cases were taken against China-accounting for nearly one-fifth of all the cases. Table 5.7 shows the distribution of anti-dumping cases of the United States during 2002-08. It shows that China has the highest number either in the investigation and adjudication in the US anti-dumping cases or for the anti-dumping tax rates being imposed. Trade barriers imposed on goods made in China are harsh and discriminatory. Again, following the discussion of this chapter, it is clear that for the long-term interest of Chinese exporting enterprises, it is critical for them to move up the value chain in producing and exporting their products. This is because those high value-added and more differentiated products better match consumer preferences in industrialised countries and therefore are less likely to be subject to anti-dumping claims.

Table 5.7 US anti-dumping claims against its most frequently investigated trading partners

\begin{tabular}{|l|l|r|r|r|r|}
\hline Rank & Partner & Investigations & Injury (share) & $\begin{array}{c}\text { Only country in } \\
\text { investigation (share) }\end{array}$ & Mean duty \\
\hline 1 & China & 56 & $44(78.6 \%)$ & $24(42.9 \%)$ & $158.4 \%$ \\
\hline 2 & India & 14 & $5(35.7 \%)$ & $2(14.3 \%)$ & $44.1 \%$ \\
\hline 3 & Korea & 10 & $3(30.0 \%)$ & 0 & $27.8 \%$ \\
\hline 4 & Japan & 9 & $3(33.3 \%)$ & $5(55.6 \%)$ & $104.0 \%$ \\
\hline 5 & Germany & 7 & $2(28.6 \%)$ & 0 & $78.7 \%$ \\
\hline 6 & Mexico & 6 & $3(50.0 \%)$ & 0 & $26.4 \%$ \\
\hline 7 & South Africa & 6 & $1(16.7 \%)$ & $3(50 \%)$ & $121.39 \%$ \\
\hline 8 & Canada & 6 & $1(16.7 \%)$ & $5(83.3 \%)$ & $20.88 \%$ \\
\hline & Total & 114 & $62(54.4 \%)$ & $39(34.2 \%)$ & $128.5 \%$ \\
\hline
\end{tabular}

Sources: Bown (n.d.); USITC (2008).

\section{Conclusions}

This chapter examined the changes in China's export structure from two dimensions: the technological content and the quality of exporting products. We find that after considering the impact of international vertical specialisation, the technological content of Chinese exports demonstrates a pattern of change that is different from what the literature has portrayed to be the case. The proportion of high-tech products has dropped significantly, 
and the domestic technological content of exports has not increased significantly. The supernormal export growth model mentioned by Rodrik (2006) and others does not exist in China after removing processing trade from China's total trade.

A policy implication is that China has long been dependent on low-cost and low-quality products to boost its export growth. The high-tech content of China's exports is strongly dependent on foreign technology embodied in processing trade. The chapter points out that such an export growth model has a number of risks and therefore cannot be sustained. It is therefore necessary to alter the pattern of China's export growth in the future. China has now become the largest manufacturing producer in the world. The next task is to ensure that Chinese firms move up the value chain in producing high-quality products in the next phase of their growth and development. For enterprises to be more innovative, it is important for the Government to implement policies on innovation through increasing $\mathrm{R} \& \mathrm{D}$ expenses and investment for education and training. It is also important to deepen institutional reform, including those reform measures undertaken at the firm level, such as changes in corporate governance addressing innovation issues through proper incentives. In realising this, China can complete the shift from relying predominantly on the traditional strategy of low-cost price competition to relying mainly on the quality-oriented strategy of non-price competition on global markets.

\section{Bibliography}

Aiginger, K. 1995, The unit value as a complementary indicator for the assessment of the competitive position of the USA, EU and Japan, Paper presented to the conference On the Future of Industry in Advanced Societies, MIT, Boston.

Aiginger, K. 1997, 'The use of unit values to discriminate between price and quality competition', Cambridge Journal of Economics, vol. 21, no. 5, pp. 571-92.

Amiti, M. and Freund, C. 2008, An anatomy of China's export growth, Policy Research Working Paper Series 4628, The World Bank, Washington, DC.

Bown, C. n.d., Anti-Dumping Database Version 5.0, Brandeis University, Waltham, Mass., $<$ http://www.brandeis.edu/ cbown/global_ad/>

Cui, L. and Syed, M. 2007, The shifting structure of China's trade and production, IMF Working Paper WP07-214, International Monetary Fund, Washington, DC.

Fontagné, L., Gaulier, G. and Zignago, S. 2008, 'Specialization across varieties and NorthSouth competition', Economic Policy, vol. 23, no. 53, pp. 51-91.

Garnaut, R. 2010, 'Macroeconomic implications of the turning point', China Economic Journal, vol. 3, no. 2 (July), pp. 181-90.

Hummels, D. and Klenow, P. 2005, ‘The variety and quality of a nation's exports', American Economic Review, vol. 95, pp. 704-23.

Information Center of China Customs various years, China Customs Statistics, Information Center of China, Beijing. 
Lall, S. 2000, 'The technological structure and performance of developing country manufactured exports, 1995-1998', Oxford Development Studies, vol. 28, no. 3, pp. 337-69.

Li, K. and Wang, X. 2009, 'China's foreign trade: trends and issues after WTO accession', in C. Chen (ed.), China's Integration With the Global Economy, Edward Elgar, Cheltenham, UK, pp. 19-36.

Li, K., Song, L. and Zhao, X. 2010, 'Component trade and China's global economic integration', in A. U. Santos-Paulino and Wan, G. (eds), The Rise of China and India: Impacts, prospects and implications, Palgrave Macmillan, New York, pp. 241-61.

McKay, H. and Song, L. 2010, 'China as a global manufacturing powerhouse: strategic considerations and structural adjustment', China and World Economy, vol. 18, no. 1 (February), pp. 1-32.

Rodrik, D. 2006, 'What's so special about China's exports?', China and World Economy, vol. 14, no. 5, pp. 1-19.

Schott, P. 2008, 'The relative sophistication of Chinese exports', Economic Policy, vol. 53 (January), pp. 5-49.

Steinfeld, E. S. 2007, 'Innovation, integration, and technology upgrading in contemporary Chinese industry', in Karen R. Polenske (ed.), The Economic Geography of Innovation, Cambridge University Press, UK, pp. 289-309.

Thirlwall, A. P. 2006, Growth \& Development: With special reference to developing economies, [Eighth edition], Palgrave Macmillan, New York.

United Nations Statistics Division (UNSD) n.d., United Nations Commodity Trade Statistics Database, United Nations Statistics Division, New York.

United States International Trade Commission (USITC) 2008, Import Injury Investigations. Case statistics (FY 1980-2007), December 2008, United States International Trade Commission, Washington, DC.

Wang, D. and Cai, F. 2009, 'The demographic dividend and sustainability of China's economic growth', in F. Cai and D. Yang (eds), The China Population and Labour Yearbook. Volume 1: The approaching Lewis turning point and its policy implications, Brill, Leiden and Boston, Mass., pp. 65-83.

Yao, Y. and Zhang, Y. 2008, 'Dynamics of the domestic technological contents of China's exports, evidence from the whole country and from Jiangsu Province and Guangdong Province', Social Science in China, no. 2 (March), pp. 67-82. 